\title{
International Newsletter for the History of Education (INHE) - organ ISCHE (ISSN 0 254-8569)
}

Międzynarodowa organizacja historyków wychowania: International Standing Conference for the History of Education (ISCHE), działająca od 1979 r., wydaje swój organ pod wyżej wskazanym tytulem. Jest on swoistym lącznikiem informacyjnym pomiedzy historykami wychowania na całym świecie. Pismo ukazuje się w Hanowerze, a jego redaktorem $z$ ramienia ISCHE jest prof. dr Manfred Heinemann (adres: Editor Prof. Dr Manfred Heinemann, Lüerstr. 3 D-30175 Hannover, Germany). Pismo posiada swoich przedstawicieli we wszystkich krajach świata. Przedstawicielem pisma na Rzeczpospolitą Polską jest prof. dr hab. Julian Dybiec (UJ) - adres: Ul. Kaliny 4/14 PL 31 - 465 Kraków.

Pismo zamieszcza sprawozdania z międzynarodowych sesji ISCHE (szerzej o tych sesjach patrz dwumiesięcznik NAUKA POLSKA) oraz działalności międzynarodowych grup roboczych ISCHE, które pracują stale lub okresowo w interwałach pomiędzy sesjami ISCHE. Zamieszcza też informacje o kolejnych sesjach ISCHE, ich lokalizacji, tematach, terminach, kosztach udziału itp. Sporadycznie ukazuja się także eseje naukowe.

Publikuje się również informacje o międzynarodowym ruchu naukowym $w$ dziedzinie historii wychowania, m.in. o pracach narodowych organizacji historyków wychowania, zwoływanych przez nie konferencjach naukowych krajowych i zagranicznych oraz sprawozdania $z$ tych konferencji.

Niezwykle cenna jest międzynarodowa bibliografia zamieszczana w piśmie. Reklamuje się publikacje poświęcone historii wychowania, glównie niemieckie.

Do 1994 r. polscy historycy wychowania (i nie tylko) otrzymywać mogli INHE bezpłatnie. Od 1995 Zarząd ISCHE i międzynarodowa sesja w Lizbonie w 1993 r. (por. Nauka Polska 1993 , nr 6, s. 120 - 121) przyjęly ustalenie o jednolitej opłacie za przynależność do ISCHE we wszystkich bez wyjątku - krajach, będącej jednocześnie formą opłaty abonamentu INHE.

Jan Hellwig

\section{KSIAZZK}

\section{Recenzje}

Franciszek Glura, Z dziejów szkolnictwa i oświaty w gostyńskiem, Gostyń 1993, Gostyńskie Towarzystwo Kulturalne, ss. $83+42$ nlb.

Podjęcie monograficznego opracowania dziejów szkolnictwa na Ziemi Gostyńskiej należy uznać za inicjatywę niezwykle cenną, $\mathrm{m}$. in. dlatego, że w literaturze historyczno - pedagogicznej brak takiego opracowania, zaś historyczne opracowanie pt. Dzieje Ziemi Gostyńskiej pod redakcja Stanislawa Sierpowskiego
(Poznań 1979) z naturainych względów ukazuje dzieje wychowania i historię szkolnictwa w dość wąskim zakresie.

Konstrukcja opraowania jest chronologiczna i obejmuje dwie części. Część pierwsza zawiera cztery rozdziały oraz tekst od Autora. Poszczególne rozdziały prezentują: szkoły gostyńskie do 
XVIII wieku (s. 7-14); pod zaborem pruskim 1793-1918 (na s. 14-36); w okresie II Rzeczypospolitej (na s. 36-62); lata wojny i okupacji (na s. 63-69) oraz noty biograficzne nauczycieli, którzy zginęli w czasie okupacji hitlerowskiej (s. 69 - 71). Wartość publikacji podnosi wykaz źródel i opracowań (s. 72-74) a także indeksy nazwisk i miejscowości (s. 75-83).

Duże znaczenie dla wartości poznawczej pracy ma, obejmujący aż 42 strony, nieliczbowany zestaw starannie dobranych ilustracji zawierających zarówno dokumenty, jak i fotografie.

Praca oparta jest na bogatych żródłach. Na zespół źródeł składają się źródła archiwalne, drukowane, wspomnienia, czasopiśmiennictwo, opracowania w postaci publikacji zwartych, wywiady oraz fotografie.

Od tej strony praca spemia $w$ zasadzie wszelkie znamiona opracowania naukowego.

W moim jednak przekonaniu wykaz żródeł, mimo ich bogactwa, nie jest kompletny (nie dostrzegam np. źródeł $\mathrm{z}$ bogatych archiwów kościelnych) i dołączony jedynie w formie notek bibliograficznych. Poszczególne zaś cytaty nie posiadają odnośników i przypisów. W szczególności cytaty nie moga pozostawać bez wskazania konkretnego źródła, z którego zostały zaczerpnięte. Braki te należy uznać za poważne niedopatrzenie, w znacznym stopniu obniżające wartość dokumentacyjną pracy.

Wiele faktów wzmiankowanych przez autora (np. Akademia Lubrańskiego, działalność Edmunda Bojanowskiego, Towarzystwo Naukowej Pomocy im. Karola Marcinkowskiego, doskonalenie nauczycieli, tajne nauczanie w Wielkopolsce itp.) posiada swe opracowania monograficzne $\mathrm{i}$ do nich także należałoby się odwołać.
Wydaje się również, że w odniesieniu zwlaszcza do szkolnictwa parafialnego w okresie średniowiecza, renesansu, reformacji, epoki baroku, czy oświecenia, gdy szkolnictwo to znajdowało się pod opieka archidekanatu śremskiego i dekanatu krobskiego - źródła mogłyby być jeszcze bogatsze, gdyby dokonać analiz materiałów $z$ wizytacji kościelnych $w / w$ dekanatów, a znajdujących się w Archidiecezjalnym Archiwum w Poznaniu. Warto tu zwrócić uwage na pracę Stanisława K. Olczaka, Szkolnictwo parafialne $w$ Welkopolsce w ХИI $\mathrm{i}$ ХИII $w$. Lublin 1978.

W moim przekonaniu w odniesieniu do okresu reformacji $w$ zbyt nikłym zakresie ukazano wpływ Leszna - swoistej stolicy wielkopolskiego innowierstwa (przynajmniej w pewnych latach) - na szkolnictwo. Bardzo skrótowo potraktowano też problemy tajnego nauczania w okresie okupacji hitlerowskiej w Wielkopolsce, które na tym obszarze, wówczas tzw. Kraju Warty, było mimo represyjnej polityki okupanta, bardzo bujnie rozwinięte w wielu formach.

W sumie otrzymaliśmy pracę kwalifikująca się do rzędu prac o znamionach poularno-naukowych. Wypelnia ona lukę w naszej literaturze historyczno - pedagogicznej i może spelniać ważną rolę $w$ dalszych pracach naukowo - badawczych nad opracowaniem dziejów nie tylko oświaty gostyńskiej, ale pełniejszej syntezy wielkopolskiej oświaty i szkolnictwa.

Ma ona także ważny akcent $w$ rozwoju naukowo-badawczym ruchu regionalnego. Sponsorami powstania pracy były bowiem Gostyńskie Towarzystwo Kulturalne, Kuratorium Oświaty w Lesznie oraz Towarzystwo Miłośników Ziemi Kościańskiej.

Jan Hellwig

\section{Danuta Koźmian, Poglądy spoleczno-pedagogiczne Aleksandra Kazimierza Patkowskiego (1890-1942), Szczecin 1994, Wydawnictwo Naukowe Uniwer- sytetu Szczecińskiego, ss. 144.}

W nurcie prac biograficznych powstała interesująca publikacja D. Koźmian poświęcona działaczowi spolecznemu, pedagogowi i regionaliście z okresu międzywojennego Aleksandrowi Patkowskiemu.
Praca ta jest cenną także $\mathrm{z}$ tego powodu, że z pokaźnego dorobku pisarskiego tegoż autora, liczącego ponad 151 artykułów i prac zwartych oraz 44 recenzji, po 1945 roku ukazały się chyba tylko 2 publikacje: wybór pism 